\title{
The Effect of Security and Trust on Online Purchasing Decisions at Shopee by Kadiri University Students
}

\author{
Ariadi Santoso* \\ Faculty of Economic \\ Kadiri University, Indonesia. \\ ariadi_santoso@unik-kediri.ac.id
}

\author{
Kartika Yuliari \\ Faculty of Economic \\ Kadiri University, Indonesia. \\ kartikay@unik-kediri.ac.id \\ Priyo Priyantoro \\ Faculty of Economic \\ Kadiri University, Indonesia. \\ priyo.priyantoro@unik-kediri.ac
}

\author{
Sudjiono \\ Faculty of Economic \\ Kadiri University, Indonesia \\ sudjiono@unik-kediri.ac.id
}

\begin{abstract}
The development of technology was very fast, it can be felt in various fields ranging from transportation and electronic communication. Therefore, people's lifestyles today are changing. one of the changes that occur is a change in how to shop from offline to online. Now shopping can be done online through e-commerce. E-commerce is a means of buying and selling media that has certain characteristics and characteristics. According to the characteristics of its users, ecommerce is classified into 3 types, namely Business to Consumer (B2C), Business to Business (B2B), and Consumer to Consumer (C2C). Where one form of e-commerce is a shopee market place which is a C2C business, this study involved 200 students as respondents at Kadiri University, the sampling in this study using a purposive random sampling process with quantitative analysis. Hypothesis testing with multiple linear regression analyses because this study aims to reveal the relationship between the dependent variable and the independent variable with SPSS. The results of the research are: that the safety variable significantly influences online purchasing decisions at shopee, the trust variable significantly influences online purchasing decisions at shopee, and the safety and trust variables influence simultaneously on online purchase decisions at shopees.
\end{abstract}

Keywords: E-commerce, Purchasing Decisions, Security, Trust.

\section{INTRODUCTION}

The development of business in the era of globalization, which is increasingly rapid, encourages business people to target consumers using technology that has developed. This makes a business challenge, as well as a good opportunity for companies operating in Indonesia. The era of globalization, which is increasingly developing, is expanding the area of product marketing in Indonesia, but on the other hand, the situation has led to increasingly fierce competition, given that it is easier for companies to reach markets [1].

Technology is the process of increasing added value. The process uses or produces a product, the product produced is not separate from other existing products, and therefore becomes an integral part of a system. These technological advances greatly support the convenience of the community in carrying out activities. But now, the technology created is not only a necessity to facilitate community activities but also as a means to support business activities in the Company. [2].

The development of these technologies can be felt in various fields ranging from transportation, electronic communications, and even cyberspace. Therefore, people's lifestyles are changing because of the influence of these technological developments, one of the most striking of these technological developments in the gadget and the tendency to move in cyberspace such as shopping online [3].

Internet users in Indonesia alone have begun to develop since 1990. Based on data from the Association of Indonesian Internet Service Providers (APJII), internet users in Indonesia in 2014 reached 88.1 million users from a population of 252.4 million people or around $30 \%$. Java Island is the island with the most internet users in Indonesia, with 52 million internet users. Then, it increased in 2016 to 132.7 million internet users from a total population of 256.2 million people or around 53\%. while the latest data in 2018 shows that the total population of Indonesia is 264.16 million with a total of 171.17 million internet users, representing $64.8 \%$ of the total population. From these data, internet users consist of various groups ranging from homemakers, children, students, students, business people, from the age range of 8-45 years.

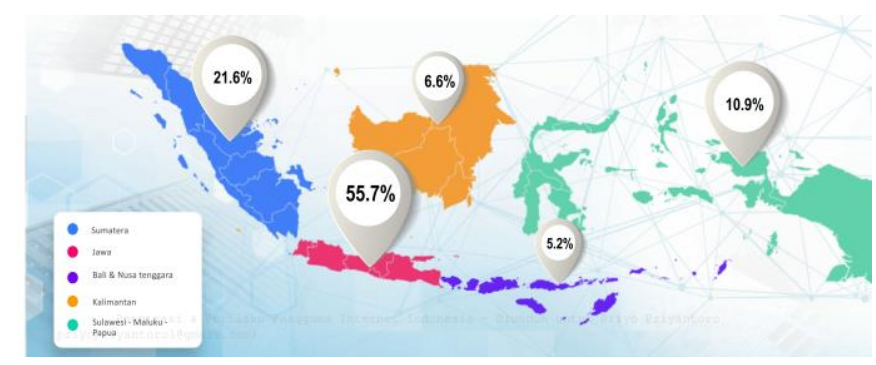




\section{Figure 1. Distribution of Internet Users by Island}

Based on the picture above, it can be seen that the spread of Internet users by islands in Indonesia in 2018. Of these, Java has the largest number of users with a percentage of $55.7 \%$, followed by Sumatra with $21.6 \%$, Sulawesi Maluku - Papua with a percentage of $10.9 \%$ followed by Kalimantan Island with $6.6 \%$, and the last position was Bali with $5.2 \%$.

One use of the internet in life is to be used as a means of shopping online. Through the online shop, the buyer can see various products offered through the web promoted by the seller. Online shopping allows both buyers and sellers do not meet face to face, so this allows the seller to have the opportunity to get buyers from abroad. Plus, if we buy things in an offline store, these items will be more expensive than if we buy online [4]. As an example of several Matahari Department Store that we usually find at the Plaza are closed due to intense modern retail competition in big cities, and competition is very intense, especially in ecommerce.

E-commerce is a means of buying and selling media that has specific characteristics and characteristics. According to the characteristics of its users, e-commerce is classified into three types namely Business to Consumer (B2C), Business to Business (B2B) and Consumer to Consumer (C2C) [5]. Among the three business models, $\mathrm{C} 2 \mathrm{C}$ is the most popular business model in Indonesia today. One of the $\mathrm{C} 2 \mathrm{C}$ models is the business marketplace.

To make it easier to access the marketplace the developers launch an application-based marketplace system that can be downloaded on a smartphone. There are several advantages of selling in the marketplace, one of which is the absence of rental fees. Sellers only need to register and then promote the products they sell. Another advantage that can be felt by buyers is the number of sellers who trade in a marketplace that sells a variety of goods with different price variations so that buyers can choose and compare which sellers to choose. More and more buyers and sellers who are members of the marketplace can be a parameter of the success of the marketplace, this is a marketplace concept. One of the marketplaces with the most users in Indonesia is shopee [6].

Shopee is here to make it easier for anyone to register entrepreneur's products and manage inventory, and facilitate financial transactions. Launched in limited (soft launch) in June 2015, Shopee has accumulated several million active users throughout Indonesia, Singapore, Malaysia, Thailand, Vietnam, the Philippines and Taiwan.

Based on data collected by Iprice, shopee is one of the online shopping sites which ranks first for the number of active users in Indonesia and ranks first as well as the number of downloads in 2019. This means that shopee is one of the most trusted online shopping sites. used by consumers.

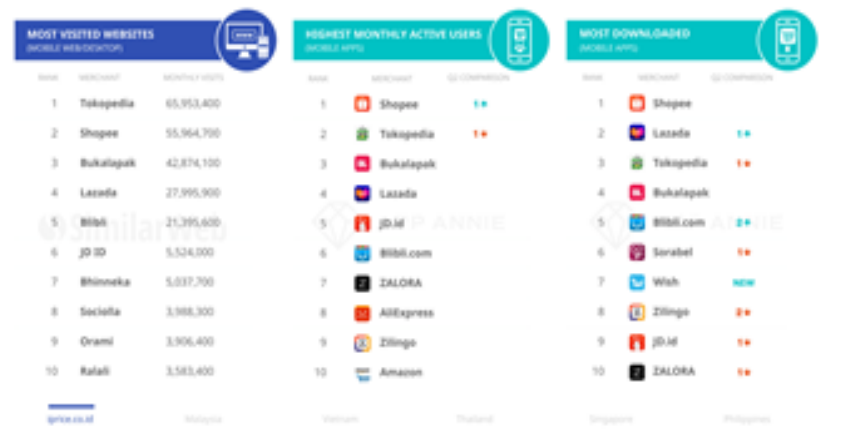

Figure 2. Ranking of Marketplace in Indonesia

One factor that influences online shopping decisions is safety in transactions. Security is the ability of an online store to maintain and control security on data transactions. Many online shopkeepers often cheat by cheating to get big profits. Consumers need to be careful when making online purchases by knowing tips on how to shop safely online. In addition, consumers need to ensure that the online shop account is a real account [7].

Security and privacy perceptions can be important aspects that can affect the satisfaction and attractiveness of consumer applications in conducting business transactions online. Because the perception of security and privacy online shopping is still considered low when compared to shopping offline. To create a sense of security and avoid online fraud, a buyer can first check the presence of "shanties" from the online store. Security is one of the important problems faced by internet users [8].

Crimes in internet media are very large and have various forms for several reasons. First, the identity of individuals, or organizations in the internet world is easy to fake, but difficult to prove legally. Second, it does not require large economic resources to commit crimes on the internet [9].

According to Raman Arasu and Viswanathan A. safety indicators include:

1. Safety guarantee.

2. Data confidentiality.

Indicators of safety variables according to (Maulina Hardiyanti, 2012) [10]

1. Transparency of witnesses.

2. Ease of transactions Cash On Delivery or transfer.

3. Proof transaction through the receipt number.

4. Citra online seller.

5. Product Quality.

According to the study Kevin Muhammad Yandhria Son (2016), Fachrizi Alwafi, Rizal Day Mag Pulse (2016), states that affect the security verification mi nat buy Konsum en. Later studies Toni Hidayat (2016) became clearer right that the security of influence on purchase decisions, as opposed to research Isnain Son B, Thunder Typhoon H, SE, M. Kom (2014) research states that the security variables that negatively ti increased insignificantly to the decision of the buyer 's.

Security in dealing with trust transactions is a factor that influences purchasing decisions. Consumer trust is the belief of a consumer that someone else has integrity and can be trusted, and the person he trusts will fulfill all his obligations in conducting transactions as expected [11]. In Kusumatuti's opinion, purchasing decisions made by customers involve customer confidence in a product so that 
self-confidence arises over the truth of the actions taken. The customer's confidence in the purchasing decision he made represents the extent to which the customer has confidence in his decision to choose a product [12].

Muhamad Nopran's research (2016) proves that customer trust is the first factor that becomes a consideration in buying a product. This is because before the product is purchased by customers, producers and companies must be able to create customer confidence in the products offered, to attract attention and arouse customer interest and confidence in the products being marketed. Muhamad Nopran also said that if consumers trust the online store provided by the company, it would enable them to increase their desire to make online purchases, this understanding generally controls online transactions that have a positive effect on consumers' decisions to make purchases.

McKnight and Chervany mention the components of trust are integrity, benevolence, competency and predictability. The components of trust are as follows [13]:

\section{Integrity}

It is honesty and the ability to keep promises from trusted parties. Integrity related to how the behavior or habits of sellers in running their business. Integrity can be seen from the point of openness), fulfillment, loyalty, honesty, interconnectedness and reliability.

\section{Benevolence}

is the attention and motivation to act in the best interests of the customer by the supplier of the good. Kindness is the willingness of the seller to provide mutual satisfaction between himself and the customer. The seller is not merely pursuing maximum profit, but also has great attention in realizing customer satisfaction. This component includes attention, empathy, confidence and acceptability.

3. Competency

Is the ability of the seller to carry out the needs of customers. In this case, how the seller can provide, serve to secure transactions from interference from other parties. This means that customers get a guarantee of satisfaction and security from the seller in making transactions. This component includes experience, institutional endorsement and ability in science.

4. Predictability

It is a consistency of behavior by the seller. The ability of the seller to provide certainty of the goods sold, so that customers can anticipate and predict the seller's performance. This component includes the seller's selfimage, predictable risks or consequences and consistency.

Research conducted by Jia Shen is about the effect of perceiving usefulness, perceived ease of use, a tendency to social comparison, and trust in online purchasing decisions. The results obtained that the trust (trust) has a significant positive effect on the purchase decision of a product. while other research conducted by Septii Mauludiyahwati related to the Effect of Trust, Safety, Service Quality and Risk Perception Using E-Commerce on Online Purchasing Decisions, the results show that trust significantly influences purchasing decisions.

Purchasing decision is a buying decision process not just knowing various factors that will influence the buyer, but based on the role in the purchase and the decision to buy. There are five roles that occur in decisions [14]:

1. Initiator, the person who first suggests buying a particular product or service.

2. Giver of influence, people whose views / advice give weight in making final decisions.

3. Decision maker, the person who determines part or all of the purchase decision.

4. Buyers, people who make real purchases.

5. Users, people who consume or use products or services.

The decisions making process in purchasing products is influenced by consumer behavior itself. There are five stages that consumers go through in the buying process according to Bilson Simamora, that is: [15]:

1. Introduction to the problem

The buying process starts when the buyer is aware of a problem or need. Buyers feel the difference between the real situation with the desired state.

\section{Search for information}

A consumer who is starting to get excited might find a lot of information. Information seeking consists of two types according to level. The first is increased attention, which is characterized by a moderate search for information. Second, active information retrieval is done by finding information from all sources.

\section{Alternative evaluation}

This stage consists of two actions, namely setting purchase objectives and assessing and holding a selection of purchase alternatives and purchasing goals. After purchasing goals are set, consumers need to identify alternatives such as money, information, time and the risk of making mistakes.

\section{Purchase decisions}

Here consumers must decide on each component of the purchase, what they buy, how to buy. Or where to buy.

\section{Behavior After Purchase}

After buying a product, consumers will feel a certain level of satisfaction or dissatisfaction. If the consumer is satisfied with the product, the consumer will make a repeat purchase, and even inform other customers, but if the consumer is dissatisfied with the product, the consumer will be disappointed and will not make another purchase of the product.

The use of the internet is increasingly popular among young people, including students. Students are a part of the community that is very close to the problem of access to information and the world of the internet. Ranging from social networks, news, videos, photos to shopping. Various facilities presented by the internet give a new color in terms of shopping [16]. Shopee online shopping is also in demand by various groups, as is the case with students, they choose Shopee because Shopee relies on free shipping, has a complete category and Shopee guarantees that goods received are in good condition.

Based on the phenomenon that occurs that the safety and trust variables are one factor in deciding online purchases. However, some of these variables in previous studies 
conducted there are still some that do not have a significant influence on online purchasing decisions. So in this case the researcher wants to do a test or re-research to determine the effect of safety and trust on purchasing decisions at shopee at Kadiri University students.

\section{METHOD}

This study uses quantitative methods, namely research data in the form of numbers and analysis using statistics (Sugiyono, 2012: 23). Quantitative research emphasizes testing theories through measuring research variables with numbers and conducting data analysis with statistical procedures. The variables examined in this study are security and trust as an independent variable (the independent variable) and purchasing decisions as to the dependent variable (the dependent variable) [17].

The analysis technique for this research model is a statistical approach through multiple linear regression analysis with statistical software processing namely SPSS version 22. Multiple linear regression analysis is used to determine the effect of independent variables on the dependent variable.

Data collection methods in the study carried out by observing, giving questionnaires (questionnaire) and by interview. While the measurement of variables is done by using a "Likert Scale" which measures the attitude of respondents with a score of respondents on a scale of 1-5

The operational definitions and research variables are as follows:

1) Research Variables

The independent variable is given the symbol $\mathrm{X}$ which is Security and Trust. Whereas the dependent variable is given the symbol Y, the Purchase Decision.

2) Operational definition

$>$ Independent Variable

- Security (X1)

○ Transaction guaranteed.

- Ease of transaction

- Proof of transaction

- Image of online seller.

○ Product quality

- Trust (X2)

- Integrity

- Benevolence

- Competency

- Predictability

- Purchasing Decisions (Y1)

- Has the benefit

- According to the needs

- Accuracy in purchasing products

- Repeated purchase

Measurement of variables is done by using the "Likert Scale". Which of these scales measures the attitudes of respondents, where respondents score on a scale of 1-5.

Based on the problems that exist between security variables and trust in online purchasing decisions. Here is a description of the framework of thinking in research:

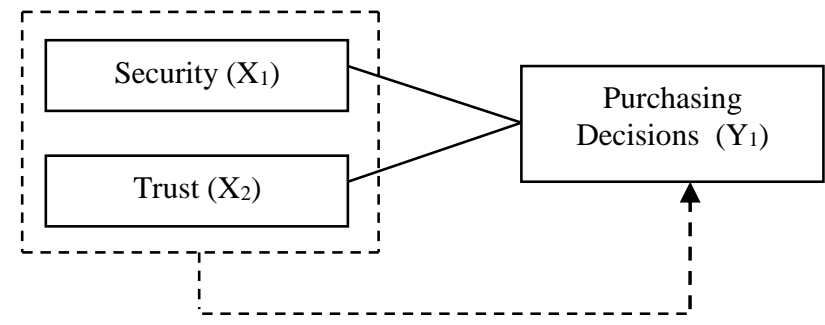

Figure 3. Thinking framework

The hypothesis is a temporary answer to the formulation of a research problem. Based on the framework of thinking above, the hypothesis formulation is taken as follows:

1. Security has a significant effect on purchasing decisions on online shopee

2. Trust has a significant effect on purchasing decisions on online shopee

3. Safety and trust variables simultaneously influence the purchase decision on the online shopee

\section{RESULT AND DISCUSSION}

\section{A. Multiple Linear Regression Analysis}

1. Characteristics of Respondents

This study used 200 respondents from Kadiri University students. Following are the characteristics of respondents based on semester level and gender:

Table 1: Characteristics of Respondents

\begin{tabular}{|l|l|l|l|l|l|}
\hline \multicolumn{2}{|l|}{ Semester } & \multicolumn{3}{l|}{ Gender } \\
\hline 2 & 24 & $12 \%$ & Male & 42 & $21 \%$ \\
\hline 4 & 60 & $30 \%$ & Female & 158 & $79 \%$ \\
\hline 6 & 84 & $42 \%$ & & & \\
\cline { 1 - 2 } 8 & 32 & $16 \%$ & & & \\
\cline { 1 - 2 } & & &
\end{tabular}

\section{Normality test}

A normality test is done to see whether the residual value is normally distributed or not. Normality test aims to test one of the basic assumptions of multiple regression analysis, namely the independent and dependent variables must be normally distributed or close to normal (Ghozali, 2011).

Figure 4. Normality test

Normal P-P Plot of Regression Standardized Residual 


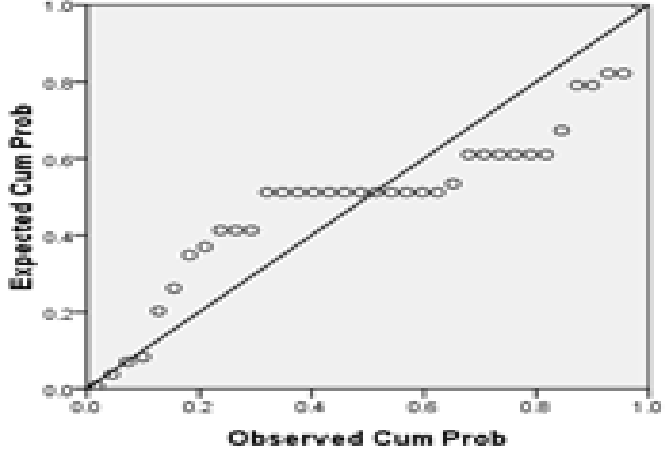

From the histogram graph above shows that the points spread and follow diagonal lines, thus it can be concluded that the data is normally distributed. Based on these results, the regression model meets the assumptions of the normality test.

\section{Multicollinearity Test}

Multicollinearity test is performed to see whether there is a high correlation between independent variables in a multiple linear regression model (Ghozali, 2011). The statistical tools used to test multicollinearity disorders are tolerance values and variance inflation factor (VIF). If the tolerance value $>0.1$ and VIF value $<10$, then there is no multicollinearity [18]. The results of the multicollinearity test using the SPSS program are Tolerance values of less than 0.10 which means there is no correlation between independent variables Theresults of the calculation of the Variance Inflation Factor (VIF) value also indicate the same thing there is no one independent variable that has a VIF value of more than 10 . So it can be concluded that in the regression model there is no multicollinearity between independent variables.

\section{Results of Data Analysis}

The method used to test the analysis of Safety and Trustworthiness variables on Purchasing Decisions at Online Shopee by Kadiri University students is by using multiple linear regression analysis, T-test and F-test. Based on data calculations, the following results can be obtained:

Table 2: Results of Multiple Regression Analysis

\begin{tabular}{|l|r|r|r|r|r|}
\hline Model & \multicolumn{2}{|l|}{$\begin{array}{l}\text { Unstandardized } \\
\text { Coefficients }\end{array}$} & $\begin{array}{c}1 \text { Sta } \\
\text { ndardized } \\
\text { Coeficients }\end{array}$ & & \multirow{2}{*}{ Tig } \\
\cline { 2 - 4 } & \multicolumn{1}{|c|}{$\mathrm{B}$} & \multicolumn{1}{|l|}{ td. eror } & eta & & \\
\hline constant) & 2.618 & 1.191 & & 2.198 & .030 \\
\hline Security & .497 & .097 & .376 & 5.125 & .000 \\
\hline Trust & .472 & .067 & .519 & 7.063 & .000 \\
\hline
\end{tabular}

Based on the results of multiple linear regression analysis obtained by the regression equation, as follows:

$$
\mathrm{Y}=2,618+0,497 \mathrm{X} 1+0,472 \mathrm{X} 2
$$

By using a significant level of $5 \%(\alpha=0.05)$, the regression model can be interpreted as follows:

1. A constant of 2.618 means that in the above equation a constant value of 2.618 (positive) is obtained which means that if there is no influence of the security variable (X1) and Trust (X2) then the purchasing decision is 2.618 .

2. The regression coefficient value of the security variable is 0.497 which means that each increase in the security variable (X1) of one unit will result in an increase in purchasing decisions of 0.497 units. Conversely, a decrease in one unit on the security variable will reduce the purchase decision by 0.497 with other assumptions are fixed.

3. The value of the regression coefficient on the trust variable is 0.472 which means that each increase in the trust variable (X2) by one unit will result in an increase in purchasing decisions by 0.472 units. Conversely, a decrease in one unit on the variable confidence will reduce the purchase decision by 0.472 with other assumptions are fixed.

$\mathrm{T}$ test (partial test) is used to test whether each independent variable, namely security (X1), and trust (X2) has a positive and significant effect on the dependent variable, namely purchasing decisions (Y) partially. The partial test results (t test) from the Path analysis results in SPSS obtained the following results:

1. The results of the t-test statistic test for the safety variable were obtained by t-count of 5.125> t table of 1.984 with a p-value level of $0.000<\alpha$ of 0.05 , then the hypothesis was accepted. This means that trust has a significant effect on purchasing decisions.

2. The results of the $t$ test statistic test for the convenience variable obtained by tcount is 7.063> ttable for 1.984 with a p-value level of $0.000<\alpha$ of 0.05 , then the hypothesis is accepted.

Table 3: Test Results F

Anovab

\begin{tabular}{|l|l|l|l|l|l|}
\hline Model & $\begin{array}{l}\text { Sum of } \\
\text { square }\end{array}$ & Df & $\begin{array}{l}\text { Mean } \\
\text { Square }\end{array}$ & F & Sig. \\
\hline Regresion & 247.342 & 2 & 123.672 & 72.696 & $.000^{\mathrm{b}}$ \\
\hline Residual & 165.018 & 97 & 1.701 & & \\
\hline Total & 412.360 & 99 & & & \\
\hline
\end{tabular}

The results of simultaneous hypothesis testing based on the table above obtained Fcount value of 72.669> F table of 3.09 with a significant value of $0.000<\alpha=0.05$. So it can be concluded that trust and convenience have a significant effect together on purchasing decisions. It can also be interpreted that the simultaneous (simultaneous) regression test model used is appropriate (model fit) with the data.

Table 4: Determination Coefficient Test Results

(R2) Model Summary

\begin{tabular}{|l|l|l|l|l|}
\hline Model & $\mathrm{R}$ & $\begin{array}{l}\mathrm{R} \\
\text { Square }\end{array}$ & $\begin{array}{l}\text { Adjusted } \\
\text { R Square }\end{array}$ & $\begin{array}{l}\text { Std. Error of } \\
\text { the Estimate }\end{array}$ \\
\hline 1 & $.774^{\mathrm{a}}$ & .600 & .592 & 1.304 \\
\hline
\end{tabular}

Based on the results of the coefficient of determination (R2) in this study, the Adjusted R Square value of 0.592 was obtained. This shows that purchasing decisions are 
influenced by security and trust variables of $59.2 \%$, the remaining $40.8 \%$ is influenced by other factors.

\section{CONCLUSION}

Based on the results of research and discussion on safety and trust in purchasing decisions, the following conclusions can be drawn: the safety variable significantly influences (directly affects) the purchase decision of online purchasing decisions in shopees by Kadiri University students, the trust variable significantly influences ( directly influence) on online purchasing decisions at Shopee by Kadiri University students, and the security and trust variables simultaneously influence the online purchasing decisions at Shopee by Kadiri University students.

The results of this study support Jia Shen's research on the effect of perceiving usefulness, perceived ease of use, a tendency to social comparison, and trust on online purchasing decisions which show that trust variables have a positive and significant effect on purchasing decisions. The results of this study also support Septii Mauludiyahwati's research related to the Effect of Trust, Safety, Service Quality and Risk Perception Using E-Commerce on Online Purchasing Decisions, the results show that trust significantly influences purchasing decisions.

\section{ACKNOWLEDGMENT}

Researchers thank all parties who have provided support for the realization of this research. This research is expected to be beneficial for the participating universities in achieving an increase in publication of scientific papers

\section{REFERENCES}

[1] Abdelwahab, Aldukali, Ali, and ALrawimi, "Influence Of Online Security, Protection, Website Credibility And Previous After Sales Experience On The Intention To Purchase Online," Eur. J. Bus. Innov. Res., vol. 3, no. 2, pp. 1-10, 2015.

[2] E. L. R. Kore, F. Lamalewa, and A. Mulyaningsih, "The influence of promotion, trust, and convenience to online purchase decisions," Int. J. Mech. Eng. Technol., vol. 9, no. 10 , pp. $77-83,2018$.

[3] M. Pilik and E. Juřičková, "Trust And Security As Significant Factors Influencing On-Line Buying Behavior In The Czech Republic," Ekon. Manag. Inovace, vol. 8, no. 2, pp. 1805-353, 2016.

[4] Rong Li, Jae jon Kim, and jae Sung Park, "The Effects Of Internet Shoppers' Trust On Their Purchasing Intention In China," J. Inf. Syst. Technol. Manag., 2017.

[5] S. Rahi, M. A. Ghani, and F. J. Muhamad, "Inspecting the Role of Intention to Trust and Online Purchase in Developing Countries," J. Soc., vol. 06, no. 01, pp. 1-7, 2017, doi: 10.4172/2167-0358.1000191.

[6] N. Fortes and P. Rita, "Privacy concerns and online purchasing behaviour: Towards an integrated model," Eur. Res. Manag. Bus. Econ., 2016.

[7] Z. Bauboniene and G. Guleviciute, "E-Commerce Factors Influencing Consumers' Online Shopping Decision," Soc. Technol.,2015.

[8] Abdalslam.S.Imhmed.Mohmed, N. B. Azizan, and M. Z. Jali, "The Impact of Trust and Past Experience on Intention to Purchase in E-Commerce," Int. J. Eng. Res. Dev., 2018.

[9] Sfenrianto, W. Gunawan, D. S. Kelly, and R. E. Tarigan, "The use of quality, security and trust factors to improve the online purchase decision," J. Theor. Appl. Inf. Technol., 2018.

[10] D. Ardyanto, "The Effect of Ease and Trust Using ECommerce on Online Purchasing Decisions," J. Adm. Bisnis S1 Univ. Brawijaya, vol. 22, no. 1, pp. 1-8, 2015.

[11] C. C. Wang, C. A. Chen, and J. C. Jiang, "The impact of knowledge and trust on E-consumers' online shopping activities: An empirical study," J. Comput., vol. 4, no. 1, pp. 11-18, 2017, doi: 10.4304/jcp.4.1.11-18.

[12] M. Y. Wang, P. Z. Zhang, C. Y. Zhou, and N. Y. Lai, "Effect of emotion, expectation, and privacy on purchase intention in wechat health product consumption: The mediating role of trust," Int. J. Environ. Res. Public Health, 2019.

[13] M. Edwar, R. A. Agustin Diansari, and N. Fahmi Winawati, "The Factors That Affecting the Product Purchasing Decision Through Online Shopping By Students of Surabaya State University," Int. J. Educ. Res. Rev., vol. 3, no. 4, pp. 54-64, 2018, doi: 10.24331/ijere.432350

[14] M. Zendehdel, L. H. Paim, and S. B. Osman, "Students' online purchasing behavior in Malaysia: Understanding online shopping attitude," Cogent Bus. Manag., vol. 2, no. 1, pp. 1-13, 2015, doi: 10.1080/23311975.2015.1078428.

[15] R. P. Bringula, S. D. Moraga, A. E. Catacutan, M. N. Jamis, and D. F. Mangao, "Factors influencing online purchase intention of smartphones: A hierarchical regression analysis," Cogent Bus. Manag., vol. 5, no. 1, pp. 1-18, 2018, doi: 10.1080/23311975.2018.1496612.

[16] A. Leeraphong and A. Mardjo, "Trust and Risk in Purchase Intention through Online Social Network: A Focus Group Study of Facebook in Thailand," J. Econ. Bus. Manag., 2017.

[17] K. Khotimah and F. Febriansyah, "The effect of ease of use, consumer confidence and advertising creativity on online-shop consumer buying interest," J. Manaj. Strategy. dan Apl. Bisnis,2018.

[18] Y. F. Wahyuningtyas and D. A. Widiastuti, "Analysis of the Effect of Perceptions of Risk, Ease and Benefits of Online Purchasing Decisions (Case Study of Consumers of Fashion Goods on Facebook)," Kaji. Bisnis STIE Widya Wiwaha,2017. 